\section{UP-249 前立腺澏に対する局所低温照射について}

UP-250 前立腺癌に対する放射線とlow-dose CDDP 併用療法の経験

\author{
国立横須賀病院 泌尿器科”古畑泌尿器科クリニック 2
}

小川勝明" 吉田 害”岩井 博" 古畑 哲彦2)

『目的』近年わが国々でも前立腺癌の根治的放射線療法の有 るためにはいかに高線量を副作用を少なく照射するかが課題とな っている。私共は、1985〜92年に尿道、膀胱、直腸を冷却し根治 的前立腺外照射を試みた。今回これらの治療効果を検討した。 『対象及び方法』症例は国立横須賀病院にて治療したstage A〜C 照射方法: 触診、X線、C T 画像に基づき個々に計算器に入力、 左右より一軸または二軸 $120^{\circ}$ 振子照射。冷却照射は週一回 $3 \mathrm{~Gy}$ を 5〜6回行った。冷却は、1 $12^{\circ} \mathrm{C}$ の水をthree way catheterで、 膀胱尿道を還流し、直腸には $12^{\circ} \mathrm{C}$ の水 $100 \mathrm{ml}$ 入机たコンドーム つきネラトンカテーテルを留置して行った。『結果』多分割、 一部慣用分割にて統計82Gy/55Dの高線量を照射できた。現在 までの予後は、癌死が 2 例のみである。また、急性期障害では頻 尿、下痢、排尿痛など 5 例あったが、晚期障害は頻尿が 2 例之高 線量の割には少なかった。今後さらに症例を追加しての検討した い。

\section{前立腺癌 放射線冷却 局所冷却法} 効性が認められるようになってきている。そして治療効果を上げ の16例。照射装置: Theratron60 (SAD:60cm, 出力: $60 \sim 30 \mathrm{R} / \mathrm{m}$ )。

\section{徳島赤十字病院 泌尿器科"}

\author{
过雅士" 谷本 修二"上間 健造" 桜井 紀嗣1"
}

【目的】前立腺癌では根治的放射線療法, 転移巣への放射線照射 が施行されるが，一般に腫瘍内では低酸素性腫瘍細胞の增加によ り放射線感受性低下が報告されている.また, CDDPの薬理作用之 して低酸素細胞増感効果, 放射線による細胞障害加らの回復阻害 効果などradiosensitizerとしての役割が期待されている.当科では 30例の前立腺癌患者に対する放射線療法の際に low dose CDDP （1回5mg点滴静注）投与を併用したのでその経験を報告する.

【対象, 結果】年齢は51-82歳 (中央値69歳), PSは0-2が22例, 3-4が8例, 臨床病期はStageB 10例, C 8例, D 12例, 分化度は wel2例, mod 16例, por 12例, 全例に内分泌療法が施行されて おり, 照射部位は前立腺部 21 例, 骨転移巣 9例, 照射量は30-66.3 Gy（中央値50Gy），CDDP総投与量は30-205mg（中央值 $125 \mathrm{mg}$ ) であった. Grade2の副作用を5例に，Grade3の骨髄抑制を2例， 悪心嘔吐を1例に認めたが腎障害はなく，5例は外来通院で施行し た. 19例（63.3\%）で全照射期間を通じて併用投与できた。限局 癌18例では1-36ヶ月(中央値25ヶ月)の経過観察期間でPSA failure は認めていない.【結論】放射線療法之low dose CDDPの併用 は副作用も少なく, PSの悪い症例でも比較的安全にまた外来 でも施行できる。

前立腺癌 low-dose CDDP 放射線療法

\section{UP-252 前立腺癌患者の前立腺特界抗原 (PSA) と末梢血 リンハ球サブセット、単球およひ各顆粒球数の関 係 : 免废抑制を受けるエフェクター(Ef)の同定}

\author{
国立岩国病院 泌尿器科1
}

宮地 禎幸" 小武家 誠" 三宅 知子.1

【背景之目的】通常量のflutamide（375mg／日）を用いたMaximal Androgen Blockade (MAB) 療法の問題点は肝機能障害である。 我々は肝機能障害を避ける目的で1998年4月より Gn-RH agonist または除睪術単独で内分泌療法を行ってきた（単独群）が比較的 早期に再燃を認める症例が多く、1999年4月より低用量 flutamide （250mg／日）を用いたMAB療法（低用量群）を始めた。今回、 低用量flutamideによるMAB療法の安全性上臨床効果について検 討した。【対象と方法】対象は抗androgen療法単独で治療をした Stage B以上の前立腺癌患者とした。1. 低用量群と通常量群との 副作用を比較した。2. 通常量群、単独群をhistorical control とし て各群間の初回内分泌療法としての非再燃率（PSA failure）を 検討した。【結果】副作用の比較では、投与中止に至ったものは 低用量群は37例中8例 $(21.6 \%$ )、通常量群は37例中16例（43.2\%） で肝機能障害はそれぞれ1例 $(2.7 \%) 、 6$ 例 $(16.2 \%)$ であった。 初回内分泌療法上して治療した群の1年および2年の非再燃率はそ れぞれ低用量群 (28例)．は90.9\%、末到達、通常量群（16例）は $90.0 \% 、 90.0 \%$ 、単独群 (20例) は58.7\%、46.9\%であった。【結 論】観察期間が短いものの低用量flutamideによるMAB療法は通 常量群と比へ副作用が少なく、短期間での非再燃率は単独群より 優れていると考えられた。

前立腺癌 flutamide MAB療法

\section{北野病院 泌尿器科”}

山内 民男" 清水 洋祐" 高尾 典恭" 七里 泰正"

【目的】治療前末梢血リンバ球サブセット(PBLS)、単球(Mo) お よび好塩基球 $(\mathrm{Ba})$ 、好酸球、好中球数とPSA (AXSYM) 值を基に 免疫抑制を受けるEfを同定する。【対象症例・方法】年齢中央値 71歳、93例を検討。病期はB:21,C:44,D:28例、悪性度は高分化腺 癌:6, 中分化:67, 低分化:20例であった。PSA值を目的変数、PBLS, Mo,各顆粒球数を説明変数とした重回帰分析で、PSAに対するマ イナス因子を免疫抑制を受けるEfとして検討した。CD3,CD4,CD8, ヘルパー,インデューサー, 細胞障害性 (Tc) , サプレッサー（Ts）, 活 性化インデューサー/ヘルパー(Aih), 活性化サプレッサーノ細胞 障害性 $\mathrm{T}$ 細胞, $\mathrm{N} \mathrm{K}$ 細胞 $(\mathrm{NK})$ 及び活性化 B 細胞 $(\mathrm{AB})$ を測定した。 【結果】理論值より実測值が大のものをUpper群 $(\mathrm{n}=36)$ 、以下 のものをLower群に分類し、更にLower群をLower-Upper (LU) 群 $(\mathrm{n}=25) 、$ Lower-Lower $(\mathrm{LL})$ 群 $(\mathrm{n}=32) の 2$ 群に分類した。Upper 群ではPSAの平均值は313.2ng/mlで、マイナス因子はCD4,Tc,Aih, Ts,ABであった。LU群ではPSAは平均92.3で、CD4,Tc,AB,Aih,Ba, NKであった。LL群ではPSAの平均は19.8で有意なものは認めな かった。【考察】PSA值により免疫抑制を受けるEfが異なり、PSA 值20前後が免疫抑制を強く受ける境界と考えられた。へルパー系、 $\mathrm{B}$ 細胞系が強く抑制された。免疫抑制されたEfを活性化させる免 疫療法は治療効果に寄与すると考えられた。

前立腺癌 PSA 末梢血リンパ球サブセット 